Presentasi Kasus

\title{
Labioplasti dengan Teknik Millard dan Tennison Randall
}

\author{
Al Hafiz, Dolly Irfandy, Sukri Rahman, Rahmadona
}

\begin{abstract}
Abstrak
Labioskisis merupakan cacat bawaan yang umum di seluruh dunia. Dibedakan atas celah inkomplit dan komplit serta celah unilateral dan bilateral. Labioskisis ditatalaksana dengan melakukan labioplasti, antara lain dengan teknik Millard dan Tennison Randall. Dilaporkan dua kasus labioskisis, pada anak laki-laki umur 6 bulan yang dilakukan labioplasti menggunakan teknik Millard dan anak perempuan umur 4 bulan dengan teknik Tennison Randall. Masingmasing teknik labioplasti memiliki keunggulan dan kekurangan. Pemilihan teknik operasi labioplasti pada pasien labioskisis tergantung kepada kondisi pasien, keahlian dan pengalaman operator terhadap teknik tersebut.
\end{abstract}

Kata kunci: labioskisis, labioplasti, teknik Millard, teknik Tennison Randall

\section{Abstract}

Cleft lip is a common congenital defect on worldwide. Distinguished as incomplete and complete cleft, unilateral and bilateral cleft. Management of cleft lip can be done with labioplasty, such as by Millard and Tennison Randal techniques. Reported two cases patient with cleft lip, a boy 6 months old that operated with Millard technique labioplasty and a girl 4 months old that operated with Tennison Randall technique. Each technique on cleft lip operated have advantages and disadvantages. Selection of labioplasty technique in patient with cleft lip depend on the condition of the patient, expertise and experience of the operator of such technique.

Keywords: cleft lip, labioplasty, Millard technique, Tennison Randal technique

Affiliasi penulis: Bagian THT FK Unand (Fakultas Kedokteran Universitas Andalas Padang)/RSUP Dr. M.Djamil Padang

Korespondensi: rdona79@gmail.com Telp: 081363416673

\section{PENDAHULUAN}

Labioskisis dengan atau tanpa palatoskisis dan palatoskisis saja merupakan cacat bawaan yang umum diseluruh dunia. Kelainan ini paling sering menyebabkan deformitas kraniofasial yaitu sekitar $65 \%$. ${ }^{1,2}$ Rasio kejadian labiopalatoskisis pada anak laki-laki 1,5-2 kali lebih sering daripada anak perempuan. Kejadian celah pada sisi kiri dua kali lebih sering dibandingkan sisi kanan. ${ }^{1}$ Labiopalatoskisis memberikan beban resiko keuangan yang cukup besar pada keluarga dan masyarakat. Individu dengan cacat ini akan mengalami masalah asupan makanan, berbicara, mendengar dan integrasi sosial, yang dapat diperbaiki dengan operasi, perawatan gigi, terapi wicara dan intervensi psikososial. ${ }^{3-5}$
Labioskisis disebabkan oleh berbagai faktor. Pada kebanyakan kasus, disebabkan oleh mutasi gen, penyimpangan kromosom serta interaksi dari faktor genetik dan lingkungan. Faktor genetik, seperti riwayat keluarga. Faktor lingkungan termasuk faktor teratogen, seperti penggunaan fenitoin, derivat asam retinoat, ibu merokok, infeksi, nutrisi (kurangnya suplemen asam folat) dan metabolisme kolesterol. ${ }^{1,6-10}$

Labioskisis diklasifikasikan berdasarkan cacatnya atas celah unilateral dan bilateral serta komplit dan inkomplit. ${ }^{11}$ Celah komplit melibatkan seluruh bagian vertikal dari bibir atas dan sering disebut celah alveolar karena bibir dan palatum berasal dari embriologi yang sama. Celah inkomplit hanya melibatkan sebagian dari bagian vertikal bibir atas, dimana masih terlihat bagian otot dengan kulit yang utuh diatas celah bibir. Adapun jembatan diatas bibir dengan celah inkomplit disebut sebagai Simonartband. ${ }^{2,11}$ 


\section{EMBRIOLOGI}

Pembentukan bibir bagian atas melibatkan serangkaian koordinasi pada daerah frontonasal, maksila dan penonjolan wajah mandibula. Pada minggu keempat masa embriogenesis, penonjolan medial dan lateral hidung menjadi nasal plakode, dan bagian yang lebih dalam menjadi lobang. Selama minggu kelima penonjolan medial hidung bersatu membentuk philtrum, arkus sentral alveolar maksila dan palatum utama. ${ }^{2,7}$

Mengikuti periode awal pertumbuhan, program kematian sel dan ekspansi struktur, fusi aktif dari maksila, hidung bagian medial, prosesus lateral hidung, menghasilkan bibir atas pada minggu ke- $6{ }^{7}$ Pertemuan tiga unsur wajah ini juga membentuk lempeng utama, termasuk alveolus. Pada labioskisis, kurangnya derivat jaringan mesenkimal menyebabkan kesalahan posisi antara penonjolan, kegagalan jembatan epitel dan celah pun dihasilkan. Sedangkan kegagalan di satu sisi menghasilkan celah unilateral, gagal di kedua sisi menghasilkan celah bilateral. ${ }^{2,7,9,12}$

Pemeriksaan ultrasonografi pada prenatal membantu dalam mengidentifikasi masalah labioskisis dan palatoskisis. Diagnosis prenatal dari labioskisis dapat dilakukan setelah usia kehamilan 16-20 minggu. ${ }^{2,13}$

\section{ANATOMI}

Sebelum melakukan operasi labioskisis, kita harus mengetahui anatomi dari daerah nasolabial. ${ }^{14}$ (Gambar 1)

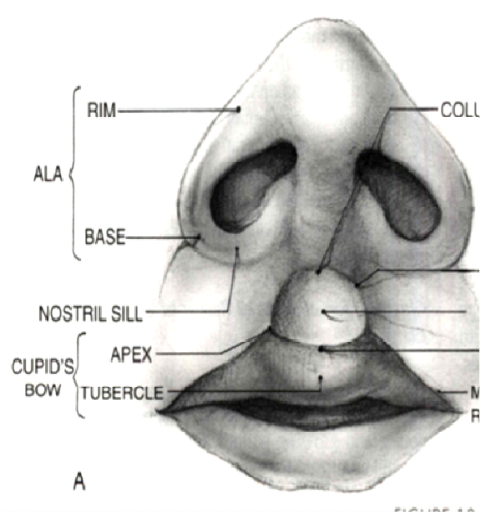

Gambar 1. Landmark normal yang penting dalam perbaikan celah pada bibir. ${ }^{14}$
Tiga deformitas utama pada labioskisis dengan celah unilateral adalah: ${ }^{14}$

1. Deformitas maksilaris adalah perpindahan anterior dengan rotasi eksternal premaksila (bagian tengah jembatan alveolar atas dan maksila timbul dari gigi seri atas).

2. Deformitas bibir adalah penurunan ketinggian vertikal di sisi celah dengan kekurangan jaringan variabel medial, abnormalnya penyisipan otot orbikularis oris.

3. Deformitas nasal adalah dipersingkatnya celah sisi kolumela dengan kartilago lateral yang lebih rendah dan melebar pada dasar alar. (Gambar 2)

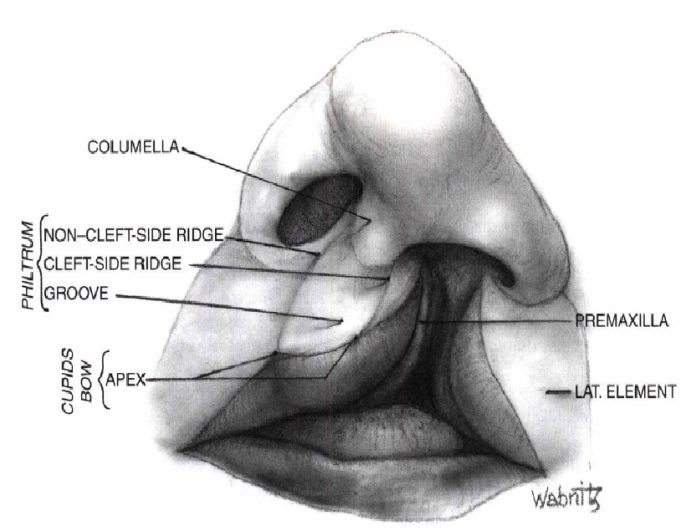

Gambar 2. Celah bibir unilateral. ${ }^{14}$

\section{KLASIFIKASI}

Veau yang dikutip oleh Chen et al, mengklasifikasikan celah bibir dan palatum menjadi 4 grup: $^{13}$

1. Celah pada palatum mole saja

2. Celah pada palatum mole dan durum

3. Celah pada bibir dan palatum unilateral

4. Celah pada bibir dan palatum bilateral

Ada perbedaan pendapat yang cukup besar mengenai waktu optimum operasi. Meskipun operasi dapat dilakukan pada hari pertama kehidupan, usia paling awal yang wajar adalah 10 sampai 14 hari setelah kelahiran, asalkan bayi mempunyai kenaikan berat badan yang normal. Aturan "rule of ten" adalah panduan yang baik, yaitu lebih dari usia 10 minggu, 
berat badan 10 pons, dan hemoglobin10 gram/dl. Usia tiga bulan diyakini sebagai saat yang paling tepat $2,12,14$

\section{TEKNIK MILLARD}

Teknik Millard disebut juga dengan teknik rotation advancement. Teknik ini dikembangkan pada tahun 1955, dengan mengembangkan konsep lateral flap advancement pada bagian atas bibir yang dikombinasikan dengan rotasi dari segmen medial. Teknik ini mempertahankan kedua cupid bow dan philtrum dimple dengan keuntungan menempatkan penutupan celah di bawah dasar alar nasi. ${ }^{15,16}$

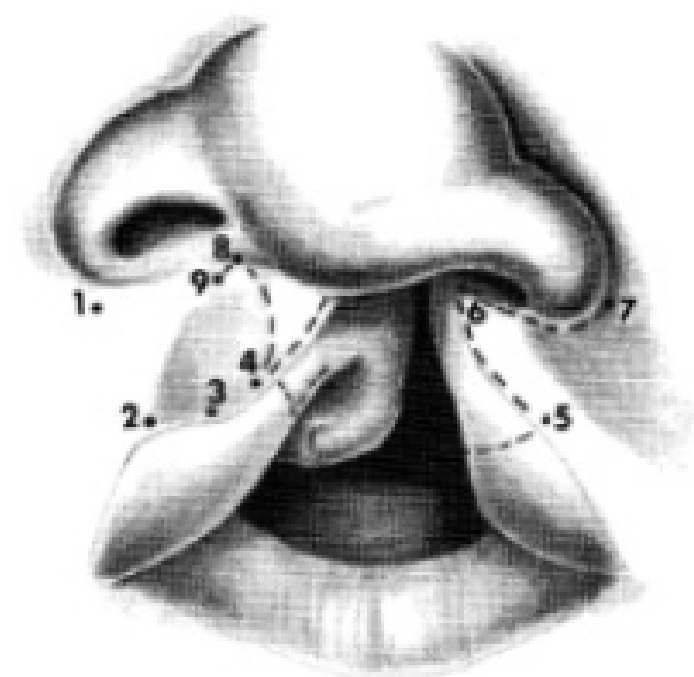

Gambar 3. Titik-titik imajiner pada teknik Millard. ${ }^{2}$

Terdapat beberapa landmark yang digunakan pada teknik ini. (Gambar 3). Titik 1, merupakan dasar alar nasi pada sisi non celah. Titik 2, titik tinggi cupid bow pada sisi non celah. Titik 3 , titik tengah cupid bow. Titik 4, titik tinggi cupid bow pada sisi celah, ditentukan dengan mengukur jarak antara titik 2 dan 3. Titik 5, puncak cupid bow pada segmen lateral celah, biasanya ditempatkan dimana white roll (vermilion kutan junction) mulai menipis. Titik 6, superior extent of the advancement flap, jarak titik 5 dan 6 harus sama dengan tinggi bibir pada sisi non celah. Titik 7 , pada sepanjang lipatan alar, sehingga jarak titik 5 dan 7 sama dengan jarak titik 1 dan 2 . Titik 8 , superior extent of the rotation incision, yang diperpanjang menunjuk 9 jika perlu, dan tidak harus menyeberangi kolum philtral pada sisi non celah. Titik 9, luasnya sayatan (jika diperlukan), mungkin diperlukan untuk mencapai putaran bawah yang memadai dari segmen bibir medial. $^{2}$

\section{TEKNIK TENNISON RANDALL}

Prosedur Tennison Randall dikenal sebagai desain geometris yang membutuhkan pengukuran prabedah yang tepat. Operasi ini dilakukan secara ketat pada prinsip-prinsip matematika, pengukuran dan seni. Keuntungan dari prosedur Tennison Randall adalah efek lip advancement antara dasar alar dan cupid bow pada sisi yang terkena. Kerugiannya teknik Tennison klasik, philtrum dimple memiliki kecenderungan untuk menjadi lebih datar. ${ }^{17}$

Landmark pada teknik Tennison Randal adalah sebagai berikut:

- Hal-hal berikut ditandai pada elemen bibir medial. Titik 1 adalah titik tengah cupid bow di perbatasan vermilion. Titik 2 adalah puncak cupid bow di sisi non-celah. Titik 3 adalah puncak cupid bow di sisi celah sehingga panjang 1-2 sama dengan panjang 1-3 (Titik 3 berhubungan dengan titik 13).

- Unsur bibir medial didorong ke arah celah tersebut, meluruskan kolumela di garis tengah. Titik 5 adalah titik di perbatasan vermilion dari elemen medial di dasar kolumela tersebut. Titik 4 adalah titik pada dasar kolumela yang berhubungan pada lubang hidung yang berlawanan. Titik 6 adalah titik di lantai lubang hidung dari elemen lateralis dengan hubungan yang sama dengan celah sisi dasar alar sebagai titik 4 pada sisi non-celah dasar alar.

- Jalur 5-3 ditarik garis.

- Titik 7 umumnya ditemukan pada garis tengah philtral sehingga sudut 5-3-7 sekitar sudut kanan.

- Garis 3-7 ditarik.

- Titik 8 terletak di perbatasan vermilion dari elemen lateral pada titik di mana ridge mukokutan menjadi ditipiskan. Jarak dari titik 8 untuk komisura mulut ipsilateral sama dengan jarak dari titik 2 ke sisi non-celah komisura mulut.

- Titik 10 adalah sekitar titik tengah 7-13, dan titik 11 adalah sekitar titik tengah 9-12.

- Lokasi titik 9 dan 12 bervariasi sesuai dengan ukuran celah dan jumlah jaringan yang tersedia. 
Titik 9 dipilih pertama pada dasar percobaan dan disesuaikan sehingga hubungan berikut ini benar:

a. Panjang 6-9 dibuat sama dengan panjang 5-13.

b. Panjang 4-2 dikurangi 5-10 sama panjang 8-11, jarak di dasar flap atau jumlah yang diperlukan untuk menghubungkan cupid bowke dalam posisi normal.

C. Panjang 8-12 sama panjang $\quad 9-12 .{ }^{14}$ (Gambar 4)

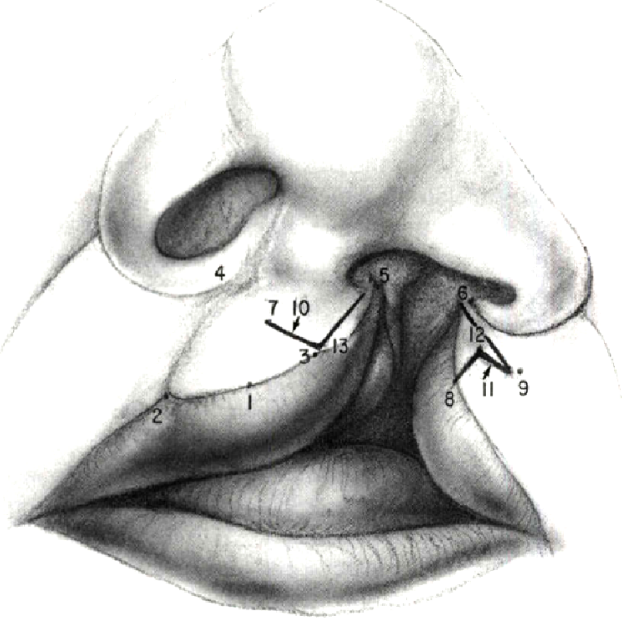

Gambar 4. Titik-titik imajiner pada teknik Tennison Randall. $^{14}$

\section{LAPORAN KASUS}

Kasus pertama

Seorang anak laki-laki umur 6 bulan dibawa ke poliklinik Plastik Rekonstruksi bagian THT-KL pada tanggal 20 Mei 2015, dengan keluhan utama celah pada bibir kiri sejak lahir. Anak masih bisa menyusu dengan baik. Riwayat ibu mengkonsumsi obat-obat anti kejang dan konsumsi alkohol waktu hamil tidak ada. Riwayat ibu merokok tidak ada. Riwayat ibu dengan diabetes melitus tidak ada. Riwayat demam waktu hamil tidak ada. Riwayat trauma waktu kehamilan trimester pertama tidak ada. Riwayat keluarga dengan celah dibibir dan/ atau langit-langit tidak ada. Bayi lahir cukup bulan dengan berat badan lahir 2600 gram, tidak ada kelainan bawaan lainnya.

Pada pemeriksaan fisik didapatkan keadaan umum sedang, anak cukup aktif, nadi 110x/menit, nafas $26 \mathrm{x} /$ menit, afebris, berat badan $7 \mathrm{~kg}$. Pada pemeriksaan telinga didapatkan telinga kiri dan kanan tidak ada kelainan. Hidung luar tampak alar nasi turun pada sisi kiri. Kavum nasi kanan lapang, konka inferior dan media eutrofi, tidak ada septum deviasi dan tidak ada sekret. Kavum nasi kiri lapang, tampak celah pada bagian 1/3 depan dasar hidung, konka inferior dan media eutrofi, tidak ada septum deviasi dan tidak ada sekret. Tenggorok dalam batas normal. Kavum oris tampak celah pada alveolar sisi kiri ukuran $\pm 0,5 \mathrm{~cm}$. Regio labialis superior tampak celah pada bibir sisi kiri memanjang dari dasar hidung sampai bibir atas ukuran $\pm 2 \times 1 \times 0,5 \mathrm{~cm}$. Pasien didiagnosis kerja dengan labiopalatoskisis kiri unilateral komplit.

Pada orang tua pasien diberikan informed consent untuk dilakukan tindakan labioplasti dalam anastesi umum. Hasil pemeriksaan darah tanggal 21 Mei 2015 , hemoglobin $11,7 \mathrm{~g} / \mathrm{dl}$, leukosit $10.320 / \mathrm{mm}^{3}$, trombosit 405.000/mm ${ }^{3}$ PT 10,4 detik, APTT 44,6 detik. Pasien dikonsulkan ke Bagian Anak untuk toleransi operasi. Dari Bagian Anak tidak ditemukan kontra indikasi mutlak untuk dilakukan tindakan operasi.

Pada tanggal 8 Juni 2015 dilakukan operasi labioplasti dengan teknik Millard. Pasien tidur telentang di meja operasi dalam anestesi umum. Dilakukan tindakan aseptik dan antiseptik. Dilakukan penandaan pada lapangan operasi dengan blue pen marker. Penandaan dilakukan pada daerah nasolabial dengan teknik Millard (rotation advancement). Dilakukan infiltrasi dengan adrenalin 1:200.000 pada lapangan operasi. Insisi dilakukan pada daerah yang sudah ditandai. Dilakukan penjahitan pada daerah otot dan mukosa dengan vicril 4.0 dan kulit dijahit dengan prolen 6.0. Operasi selesai. Pasca operasi diberikan terapi amoxicillin $125 \mathrm{mg}$ sirup $3 \times 3 / 4$ sendok teh, parasetamol $120 \mathrm{mg}$ sirup $3 \times 3 / 4$ sendok teh.

Follow up hari kedua pasca operasi, luka operasi baik, perdarahan tidak ada, demam tidak ada. Pasien minum susu dengan sendok. Pada regio labialis superior, tampak luka jahitan baik, perdarahan tidak ada. Diagnosis pasca operasi post labioplasti hari kedua. Terapi diteruskan dan pasien dibolehkan pulang. Pasien dianjurkan untuk kontrol ke poliklinik.

Kontrol tanggal 15 Juni 2015 (hari ke-7 pasca operasi),luka operasi baik, perdarahan tidak ada, demam tidak ada. Pada regio labialis superior, tampak 
luka jahitan baik, perdarahan tidak ada, tanda-tanda infeksi tidak ada.Pasien direncanakan untuk buka jahit tanggal 16 Juni 2015dalam anestesi umum.

Pada 16 Juni 2015, dilakukan pembukaan jahitan dalam anestesi umum. Pasca operasi, luka operasi baik, tidak ada celah pada regio labialis superior (Gambar 5). Pasien diperbolehkan pulang.

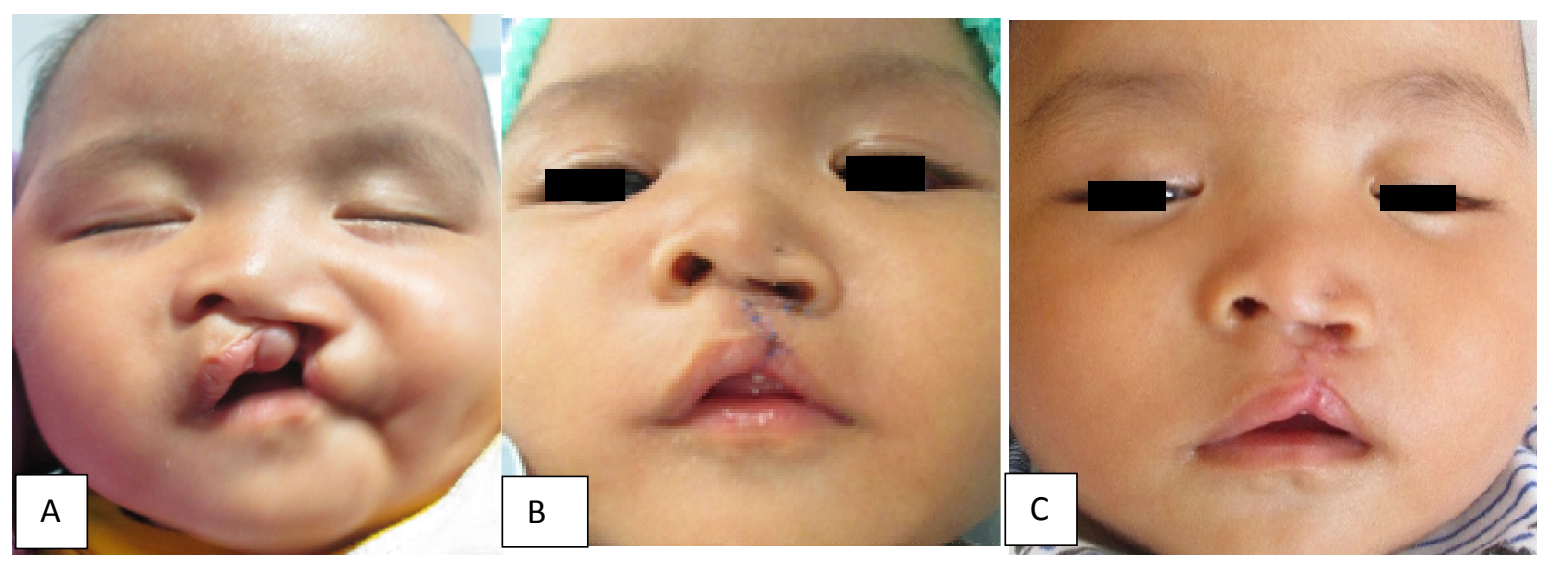

Gambar 5. A. Pasien labioskisis B. Pada regio labialis superior tampak luka jahitan baik.C.Pasca buka jahit, luka operasi baik

\section{Kasus kedua}

Seorang anak perempuan berumur 4 bulan dibawa ke poliklinik THT-KL pada tanggal 5 Agustus 2015 dengan keluhan utama celah pada bibir dan langit-langit sisi kiri sejak lahir. Riwayat ibu mengkonsumsi obat-obat anti kejang dan konsumsi alkohol waktu hamil tidak ada. Riwayat ibu merokok tidak ada. Riwayat ibu dengan diabetes melitus tidak ada. Riwayat demam waktu hamil tidak ada. Riwayat trauma waktu kehamilan trimester pertama tidak ada. Riwayat keluarga dengan celah dibibir dan/atau langitlangit tidak ada. Bayi lahir cukup bulan dengan berat badan lahir 2800 gram, tidak ada kelainan bawaan lainnya.

Pada pemeriksaan fisik didapatkan keadaan umum sedang, anak cukup aktif, nadi 108x/menit, nafas $26 x /$ menit, afebris, berat badan $4,9 \mathrm{~kg}$. Pada pemeriksaan telinga didapatkan telinga kiri dan kanan tidak ada kelainan. Hidung luar tampak alar nasi turun pada sisi kiri. Kavum nasi kanan lapang, konka inferior dan media eutrofi, tidak ada septum deviasi dan tidak ada sekret. Kavum nasi kiri lapang, tampak celah pada dasar hidung, konka inferior dan media eutrofi, tidak ada septum deviasi dan tidak ada sekret. Tenggorok dalam batas normal. Kavum oris tampak celah pada palatum durum sampai palatum mole. Regio labialis superior tampak celah pada bibir sisi kiri memanjang dari dasar hidung sampai bibir atas ukuran $\pm 2,5 \times 1 \times 0,5 \mathrm{~cm}$. Pasien didiagnosis kerja dengan labiopalatoskisis kiri unilateral komplit.

Pada orang tua pasien diberikan informed consent untuk dilakukan tindakan labioplasti dalam anastesi umum. Hasil pemeriksaan darah tanggal 6 Agustus 2015, hemoglobin 12,9 g/dl, leukosit 10.400/mm3, trombosit 498.000/mm3, PT 9,8 detik, APTT 32,3 detik. Pasien dikonsulkan ke Bagian Anak untuk toleransi operasi. Dari Bagian Anak tidak ditemukan kontra indikasi mutlak operasi.

Pada tanggal 12 Agustus 2015 dilakukan operasi labioplasti dengan teknik Tennison Randall. Prosedur operasi, pasien tidur telentang di meja operasi dalam anestesi umum. Dilakukan tindakan aseptik dan antiseptik. Dilakukan penandaan pada lapangan operasi dengan blue pen marker. Penandaan dilakukan pada daerah nasolabial dengan teknik Tennison Randall (triangular flap). Dilakukan infiltrasi dengan adrenalin 1:200.000 pada lapangan operasi. Insisi dilakukan pada daerah yang sudah ditandai. Dilakukan penjahitan pada daerah otot dan mukosa dengan vicril 4.0 dan kulit dijahit dengan prolen 5.0. Operasi selesai. Pasca operasi diberikan terapi amoxicillin $125 \mathrm{mg}$ sirup $3 \times 3 / 4$ sendok teh, parasetamol $120 \mathrm{mg}$ sirup $3 \times 3 / 4$ sendok teh. 
Follow up hari kedua pasca operasi, luka operasi baik, perdarahan tidak ada, demam tidak ada. Pasien minum susu dengan sendok. Pada regio labialis superior, tampak luka jahitan baik, perdarahan tidak ada. Diagnosis pasca operasi post labioplasti hari kedua. Terapi diteruskan dan pasien dibolehkan pulang. Pasien dianjurkan untuk kontrol ke Poliklinik. Kontrol tanggal 20 Juni 2015 (hari ke-8 pasca operasi), luka operasi baik, perdarahan tidak ada, demam tidak ada. Pada regio labialis superior, tampak luka jahitan baik, perdarahan tidak ada, tanda-tanda infeksi tidak ada. Pasien direncanakan untuk buka jahit pada 21 Agustus 2015 dalam anestesi umum.

Pada tanggal 21 Agustus 2015, dilakukan pembukaan jahitan dalam anestesi umum. Pasca operasi, luka operasi baik, tidak ada celah pada regio labialis superior (Gambar 6). Pasien dibolehkan pulang.

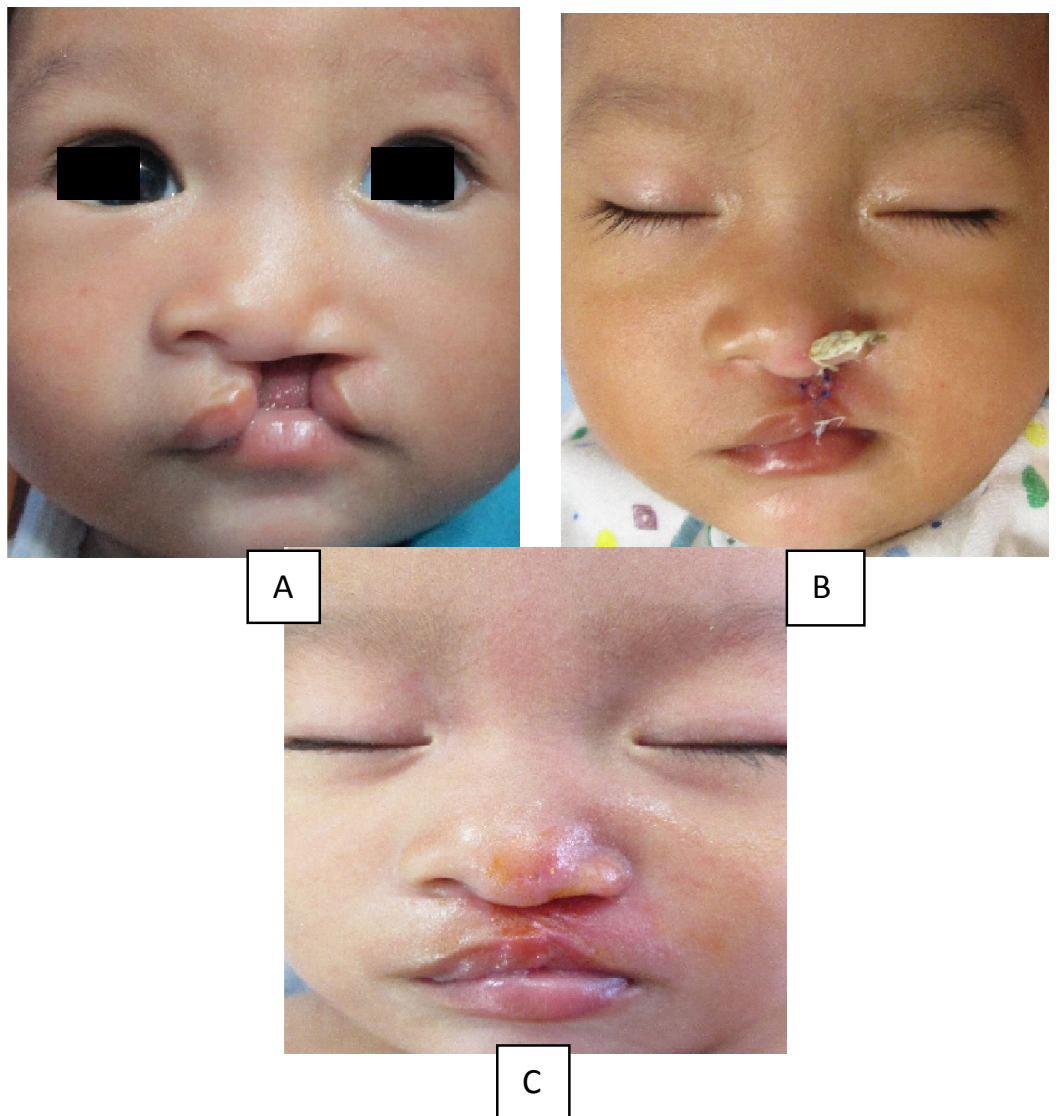

Gambar 6. Pasien labioskisis B. Pada regio labialis superior tampak luka jahitan baik.C. Pasca buka jahit, luka operasi baik

\section{DISKUSI}

Dilaporkan dua kasus, anak laki-laki umur 6 bulan dan anak perempuan umur 4 bulan dengan diagnosis labiopalatoskisis kiri unilateral komplit. Pasien dioperasi dengan teknik yang berbeda. Pada anak laki-laki dilakukan operasi dengan teknik Millard dan pada anak perempuan dilakukan teknik operasi Tennison Randall. Menurut Zayed et $\mathrm{al}^{18}$ ada banyak teknik untuk memperbaiki deformitas celah bibir unilateral yaitu teknik straight-line, teknik triangular flap dan teknik rotation-advancement. Masing-masing teknik ini memiliki kelebihan dan kekurangan. Keputusan penggunaan salah satu teknik tergantung kepada pelatihan dan paparan terhadap teknik tersebut.

Tujuan operasi pada pasien dengan celah bibir dan palatum adalah perbaikan estetika dari bibir dan hidung, penutupan celah palatum, normalisasi bicara dan mendengar, fungsi mengunyah yang normal, 
kesehatan gigi serta perkembangan psikososial yang normal. Perbaikan labioskisis unilateral adalah membentuk bibir atas dengan panjang vertikal yang sesuai dan simetris, perbaikan struktur yang mendasari dengan fungsi normal otot dan perbaikan utama hidung yang cacat. ${ }^{4,12}$

Prinsip-prinsip dasar yang perlu dipahami dalam melakukan operasi celah bibir adalah, ${ }^{18}$ 1. Menciptakan kesimetrisan pada cupid bow, 2. Membangun tuberkel yang penuh dan vermilion yang tinggi, 3. Membangun kolum philtrum dengan bentuk dan tinggi yang sama dengan kolum philtum sisi non celah, 4. Membuat kolumela yang tanpa scar dan membentuk persimpangan kolumela-labial yang simetris, 5. Memperbaiki otot orbikularis oris, 6. Membuat sulkus labial yang memadai, 7. Memperbaiki deformitas alar nasi, 8. Penutupan luka secara atraumatik.

Teknik Millard merupakan teknik rotation advancement. Teknik ini melibatkan rotasi dari elemen celahmedial. Meningkatkan panjang dan advancement dari elemen celah lateral kepada pemotongan dekat pertemuan labial-kolumela. Millard menekankan pentingnya kesimetrisan pada bibir dan hidung pada operasi awal. Kesalahan posisi akan menyebabkan asimetris dari bibir dan estestika yang tidak memuaskan. ${ }^{16,19}$ Kerugian pada teknik Millard, didapatkannya scar kontraktur vertikal dengan vermillion takik bibir atau penurunan basis alar. Scar kontraktur horizontal menyebabkan kecenderungan lubang hidung kecil. ${ }^{18}$

Metode triangular flap dipopulerkan oleh ahli bedah Tennison, Skoog dan Randall. Jaringan diambil dari elemen celah lateral dengan triangular flap dan diinsersikan ke segmen celah medial. Disebut juga sebagai unilimb Z-plasty. Metode ini mengenali masalah dari tipe bibir pendek pada penutupan dengan metode straigth line dan mencegah komplikasi dengan pemanjangan segmen medial. Biasanya triangular flap ditempatkan pada tempat yang tinggi pada philtrum tepat dibawah pertemuan labial dan kolumela. Pada teknik ini, perbaikan sisi sumbing 1 $\mathrm{mm}$ lebih pendek dari sisi non-sumbing untuk mencegah kelebihan tinggi vertikal dari bibir. Kelemahan teknik ini membuat scar yang tidak alami pada persilangan philtrum, pada tempat yang terlihat pada bibir. ${ }^{4,12,16,20}$

Holmann dan Wray seperti yang dikutip Gosman $^{20}$ membandingkan metode triangular flap dan rotation advancemant flap dalam memperbaiki celah bibir unilateral, pada kelompok studi yang berbeda, sehingga didapat perbedaan yang jelas antara keduanya. Hasil dari rotation advancement, berupa scar hipertrofi. Secara signifikan tidak ada perbedaan panjang bibir vertikal yang tercatat, walaupun pada kedua kelompok studi terdapat bibir yang pendek atau panjang pasca operasi. Tercatat bahwa rotation advancement lebih disukai, walaupun hasilnya secara statistik tidak bermakna.

Yamada seperti yang dikutip Gosman ${ }^{20}$ membandingkan morfologi wajah anak dengan celah bibir unilateral secara 3 dimensi setelah dilakukan triangular flap dibandingkan dengan rotation advancement flap ditambah triangular flap kecil (pada white roll), dan perbaikan hidung primer. Scanner optik 3D digunakan untuk mengumpulkan data permukaan wajah. Data dianalisis dengan metode antropometri menggunakan komputer. Tonjolan hidung dan simetri lubang hidung yang lebih baik pada kelompok rotation advancement. Dasar kolumela menyimpang ke sisi yang normal pada kedua kelompok, dan lebar dari lubang hidung di sisi celah meningkat secara bertahap. Pada kelompok triangular, panjang cupid bow meningkat di sisi non-celah dan puncak di sisi celah lebih rendah dari sisi non-celah dalam 1,5 tahun. Pada kelompok rotation advancement, puncak cupid bow lebih tinggi pada 2 minggu setelah operasi namun secara bertahap menurun dan menjadi simetris dalam 1,5 tahun. Perbaikan pada rotation advancement yang dihasilkan lebih baik.

Pasien pada kasus pertama yang dilakukan teknik Millard, antara bibir dan hidung terdapat kesimetrisan, walaupun alar nasi pada sisi kiri sedikit turun. Pasien pada kasus kedua yang dilakukan dengan teknik Tennison Randall, scar pada daerah philtrum terlihat pada minggu ke-2 pasca operatif.

Faktor genetik berperan pada celah bibir/palatum. Orang tua tanpa celah bibir/palatum, jika memiliki satu anak dengan celah bibir/palatum, maka anak yang berikutnya memiliki angka rekurensi $4 \%$, 
jika memiliki 2 anak dengan celah bibir/palatum, kemungkinan berulangnya celah bibir/palatum pada anak berikutnya menjadi $9 \%$. Jika salah satu orang tua dengan celah bibir/palatum, maka kemungkinan anak dengan celah bibir/palatum $4 \%$ dan jika kedua orang tua dengan celah bibir/palatum, maka kemungkinan anak dengan celah bibir/palatum meningkat $17 \%$. Pada kedua pasien, kedua orang tuanya tidak memiliki celah bibir/palatum. ${ }^{13}$

Waktu yang ideal dan metode yang tepat untuk operasi celah pada bibir dan langit-langit masih diperdebatkan. Ada banyak faktor yang menjadi pertimbangan, yaitu faktor psikososial, pertumbuhan wajah, bicara dan keselarasan pertumbuhan gigi. Sebagian besar pusat kesehatan memilih usia 3 sampai 6 bulan untuk perbaikan celah bibir dan usia 6 sampai 18 bulan untuk perbaikan celah pada palatum. ${ }^{21}$ Aturan "rule of ten" adalah panduan yang baik, lebih dari usia 10 minggu, berat badan 10 pons, dan hemoglobin $10 \mathrm{gram} / \mathrm{dl}$. Usia tiga bulan diyakini sebagai saat yang paling tepat. ${ }^{2,14,21}$ Pada pasien ini operasi dilakukan pada usia 4 bulan dan 6 bulan, dengan berat badan 10 pons $( \pm 5 \mathrm{~kg}$ ) dan hemoglobin lebih dari $10 \mathrm{gram} / \mathrm{dl}$.

Adapun perawatan pasca operasi, luka dibersihkan dari darah dan mukus dengan larutan normal salin tiap 2-6 jam. Salaf antibiotik dioleskan diatas luka jahitan setelah dibersihkan.Jaga luka dari krusta. Pasien dipulangkan 1 hari setelah operasi dan kontrol 5 hari lagidipoliklinik. Jahitan dibuka dalam anastesi umum.Pasien dianjurkan kontrol secara periodik. ${ }^{13}$ Pada kedua pasien ini pasca operasi dioleskan salaf kloramfenikol diatas luka operasi dan luka jahitan dibuka setelah kontrol 1 minggu pasca operasi, dalam anastesi umum.

Operasi palatoskisis pada pasien ini direncanakan pada usia 10-14 bulan. Adapun faktor yang menjadi pertimbangan dalam perbaikan celah pada palatum adalah, 1. Perkembangan bicara, dimana ahli patologi bicara menyatakan bahwa langitlangit harus ditutup pada usia sekitar 8 bulan, karena memungkinkan anak mengembangkan mekanisme velofaringeal yang kompeten sebelum anak bisa bicara. 2. Pembentukan gigi. Dimana penutupan palatum harus ditunda sebelum terbentuk hubungan yang optimal pada lengkungan gigi atas dengan perkembangan gigi normal yang masih oklusi. ${ }^{14,21}$

\section{SIMPULAN}

Celah pada bibir dapat dilakukan operasi labioplasti dengan menggunakan bermacam teknik, diantaranya teknik Millard dan Tennison Randall. Masing-masing teknik memiliki kelebihan dan kekurangan. Pemilihan teknik yang tepat tergantung dari pengalaman dan keahlian operator.

\section{DAFTAR KEPUSTAKAAN}

1. Jagomagi $T$, Soots $M$, Saag $M$. Epidemiologic factors causing cleft lip and palate and their regularities of occurrence in Estonia. Stomatologija, Baltic Dental and Maxillofacial Journal. 2010;12:105-8.

2. Dyleski RA, Crockett DM. Cleft lip and palate: evaluation and treatment of primary deformity. Dalam: Bailey BJ, Johnson JT, Newlands SD, editor (penyunting). Head and neck surgery otolaryngology. Edisi ke-4. Philadelphia: Lippincott Williams \& Wilkins; 2006.hlm.1338-54.

3. Lakhanpal M, Gupta N, Rao NC, Vashisth S. Genetics of cleft lip and palate- is it still patchy? JSM Dent. 2014;3:1-4.

4. Miachon MD, Leme PLS. Surgical treatment of cleft lip. Rev col bras cir. 2014;41(3):208-14.

5. Marazita ML, Mooney MP. Current concepts in the embryology and genetics of cleft lip and cleft palate. Clin plastic surg. 2004;31:125-40.

6. Selvi R, Saranya GR, Murthy J, F Mary A, Paul SFD. Chromosomal abnormality in individuals with cleft lip or cleft palate. Sri Ramachan. Journal of Med. 2009;2:21-4.

7. Cole PD, Stal S. Cleft lip repair: evaluation, planning and surgical approach to single and bilateral defect. Dalam: Butler CE, Evans GRD, editor (penyunting). Head and neck reconstruction. Edisi ke-1. China: Elsevier limited. 2009. hlm.295307.

8. Balkhi KM. The distribution and classification of clefts in patients attending a cleft lip and palate clinic in Riyadh, Saudi Arabia. Saudi Med J. 2008;5:739-42. 
9. Shkoukani MA, Chen M, Vong A. Cleft lip-a comprehensive review. Pediatric otolaryngology. 2013;1:1-10.

10. Khazaei S, Shirani AM, Khazaei M. Incidence of cleft lip and palate in Iran. Saudi med J.2011;32(4):390-3.

11. Wang TD, Milczuk HA. Cleft lip and palate. Dalam: Kennedy JF, editor (penyunting). Cumming Pediatric Otolaryngology. Philadelphia: Elsevier Saunders. 2015.hlm.106-22.

12. Talesh KT, Motamedi MHK. Cleft lip and palate surgery. Tersedia dari: URL: HYPERLINK http://dx.doi.org/10.5772/55147

13. Chen PKT, Noordhoff MS, Kane A. Repair of unilateral cleft lip. Plastic Surgery. Edisi ke-3. China: Elsevier Inc. 2013.hIm.517-48.

14. Perry RJ, Lore JM. Cleft lip and palate. Dalam: Lore JM, Medina JE, editor (penyunting). An atlas head \& neck surgery. Edisi ke-4. Philadelphia: Elsevier inc. 2005.hlm.493-505.

15. Burt JD, Byrd HS. Cleft lip: unilateral primary deformities. Plas. Reconstr. Surg. 2000; 105(3): 1043-55.
16. Meara JG, Andrew BT, Ridgway EB, Raisolsadat MA, Hiradfar M. Unilateral cleft lip and nasal repair: techniques and principles. Iran J. Pediatr. 2011;21: 129-38.

17. Clemente IF, Munguia AMN. Functional and aesthetical analysis of pimary lip corrective surgery through the rotation and advancement modified technique of unilateral cleft lip. Revis. Odont. Mex. 2011;15(3):143-51.

18. Zayed EF, Ayad W, Moustafa WA, El-Shishtawy $A H$. Unilateral cleft lip repair: Experience with millard technique and introduction to the concept of junctional zones repair. Egypt J. Plast. Reconstr. Surg. 2012;36:109-18.

19. Schendel SA. Unilateral cleft lip repair-state of the art. Cleft Palate Craniofacial Journal. 2000; 37(4):335-41.

20. Gosman AA. Cleft lip and palate II: Surgical management. Selected readings and plastic surgery. SRPS. 2007;1-93.

21. Agrawal K, Panda K. A modified surgical schedule for primary management of cleft lip and palate in developing countries. Cleft Palate-Craniofacial Journal. 2011;48:1-8. 